\title{
Modeling carbohydrate ballasting by Trichodesmium spp.
}

\author{
Angelicque E. White*, Yvette H. Spitz, Ricardo M. Letelier \\ Oregon State University, College of Oceanic and Atmospheric Sciences, 104 COAS Administration Building, Corvallis, \\ Oregon 97331, USA
}

\begin{abstract}
We report the development of a numerical model simulating vertical movement of the cyanobacterium Trichodesmium spp. Given a range of physiological parameters derived from the literature, resultant model solutions allow us to explore the ecological significance of vertical migration by Trichodesmium colonies in a stratified oligotrophic oceanic system such as the North Pacific subtropical gyre (NPSG). Whereas the dominant type of model solution results in trapping of the migrating colony at the water surface, the next most frequent type of model solution is consistent with colony migration to the average depth of the phosphocline, followed by return to the upper euphotic zone, a scenario termed P-mining. Given the temporal phasing of these migrations, our results indicate that while Trichodesmium colonies could fulfill their entire P-quota in a single phosphoclinescale migration, the minimal colony size required for such a migration would be approximately $1000 \mu \mathrm{m}$ in radius. Colonies of this size and larger have been observed in nature. However, neither the frequency of occurrence nor the relative size distributions of natural populations is known. Using published estimates of colony abundance at Station ALOHA $\left(22^{\circ} 45^{\prime} \mathrm{N}, 158^{\circ} 00^{\prime} \mathrm{W}\right.$, in the NPSG), we estimate that upward fluxes of P associated with Trichodesmium migration represent as much as $10 \%$ of the P-based export flux measured at this site. Inclusion of this simple model into coupled biophysical models should allow for better simulations of the vertical distribution of Trichodesmium biomass and thus improved representations of Trichodesmium productivity.
\end{abstract}

KEY WORDS: Vertical migration · Trichodesmium spp. · NPSG · Phosphorus cycling

\section{INTRODUCTION}

The colony-forming marine cyanobacterium Trichodesmium has been well described as a prominent diazotroph (i.e. nitrogen fixer, literally 'two nitrogen eater') in oligotrophic tropical and subtropical regions of the global ocean (Capone 2001, Mulholland \& Capone 2001, Karl et al. 2002). Primarily, this genus is a significant source of new nitrogen to otherwise nitrogen-deficient ecosystems (LaRoche \& Breitbarth 2005). Furthermore, Trichodesmium spp. are well known to form visually conspicuous surface blooms (Bowman \& Lancaster 1965, Thona 1991, Karl et al. 1992, Capone et al. 1998). During these bloom phases, Trichodesmium spp. may transiently dominate primary productivity and nitrogen (N) cycling (Karl et al. 2002).
A particularly striking feature of Trichodesmium autoecology is its ability to conduct bidirectional migrations in the vertical plane of the water column. As is common for many cyanobacteria, Trichodesmium spp. possess low-density gas vesicles that generate strong positive buoyancy (Walsby 1978). Consequentially, Trichodesmium populations are able to accumulate at the sea surface during periods of calm weather. Contrasting the capacity for flotation is the frequent accumulation of Trichodesmium biomass in subsurface maxima (Letelier \& Karl 1998, Carpenter et al. 2004). Consequently, such occurrences imply that this genus actively regulates its buoyancy, again a common trait of gas-vacuolate cyanobacteria (Oliver 1994). It has been found that Trichodesmium counteract the positive buoyancy provided by gas vacuoles via the photo- 
synthetic production of carbohydrates (Villareal \& Carpenter 1990). The balance between the production and respiration of these dense biomolecules regulates buoyancy by altering the ballast of the cell, i.e. the difference in density between the cell and the surrounding seawater.

In the North Pacific subtropical gyre (NPSG), one of the enigmas surrounding Trichodesmium is how this organism obtains the necessary phosphorus (P) required to support the formation of regular summer blooms (Karl et al. 1992). NPSG Trichodesmium blooms occur under calm conditions, after extended summer and early fall stratification periods, indicating that deep mixing events can be eliminated as a potential P supply mechanism. Karl et al. (1992) has suggested that the requisite $\mathrm{P}$ could be obtained by vertical migration to the depths of the phosphocline, a scenario termed P-mining. P-mining requires that Trichodesmium migrate to depths of approximately 100 to $150 \mathrm{~m}$ to reach the phosphocline, store intracellular $\mathrm{P}$ under light-limited, P-rich conditions, and subsequently return to the euphotic zone. Shuttling $\mathrm{P}$ from the phosphocline would allow migrating colonies to maintain balanced growth in surface waters at the expense of stored P obtained at depth (Karl et al. 1992).

Previous work in the NPSG (Letelier \& Karl 1998) found that rising colonies are more P-enriched relative to sinking colonies, a disparity coherent with $\mathrm{P}$ acquisition from depth. Furthermore, recent work by Villareal \& Carpenter (2003) reports that differences between pooled N:P ratios of rising vs. sinking colonies collected in the Gulf of Mexico were also consistent with the scenario of P-mining by Trichodesmium. However, this conclusion was not supported by data collected off North Australia by Villareal \& Carpenter (2003). These contrasting results suggest that either Pmining is intermittent in time or this behavior is confined to specific oceanic regions. Direct confirmation of Trichodesmium P-mining in the NPSG would require substantial ship time and would thus be labor intensive and costly. For these reasons, we have explored the possibility of Trichodesmium P-mining from a modeling perspective, drawing upon the empirical literature regarding carbohydrate ballasting in limnetic cyanobacteria. This theoretical approach is not intended to provide evidence for migratory P-mining. Rather the objectives of this research are to explore the hypothesis of P-mining in the NPSG using realistic parameterizations of buoyant density change to simulate vertical movement of Trichodesmium colonies and to provide insights that could inform future experimental work in the field and laboratory.

Several laboratory experiments have been conducted in order to ascribe functionality to the carbohydrate ballasting response of cyanobacteria to light
(Kromkamp \& Walsby 1990, Visser et al. 1997, Wallace \& Hamilton 1999). Kromkamp \& Walsby (1990) developed a model of vertical migration for the freshwater cyanobacterium Planktothrix aghardii (formerly Oscillatoria aghardii) based on the experimentally determined relationship between the rate of density change and photon irradiance (0 to $500 \mu \mathrm{mol}$ photons $\mathrm{m}^{-2} \mathrm{~s}^{-1}$ ). Density change as a function of irradiance was best fit with a rectangular hyperbola, whereas density loss in the dark was determined to be a linear function of the previous light history (Kromkamp \& Walsby 1990). Kromkamp \& Walsby (1992) later applied this empirically derived model to Trichodesmium and concluded that colonies could sink to depths of 100 to $200 \mathrm{~m}$. This model application, however, did not take into account water column density structure appropriate for seawater (as opposed to freshwater), nor were alternate parameterizations of density change considered given that the model was established for freshwater analogues. Clayton (2001) applied the model of Kromkamp \& Walsby (1992) to Trichodesmium using constants suitable for seawater. This study limited analysis to the impact of single parameter variations upon model solutions without examining parameter interactions or assessing the effect of multiple parameter variations. Results emphasized the need for experimental validation of the buoyancy response of Trichodesmium to light.

Closely following the experimental design of Kromkamp \& Walsby (1990), Visser et al. (1997) established an irradiance-response curve for another freshwater cyanobacterium, Microcystis spp. This work investigated the buoyancy response over a much wider range of irradiance ( 0 to $1600 \mu \mathrm{mol}$ photons $\mathrm{m}^{-2} \mathrm{~s}^{-1}$ ). Microcystis spp. exhibited maximum rates of density change at $\sim 300 \mu \mathrm{mol}$ photons $\mathrm{m}^{-2} \mathrm{~s}^{-1}$, with strong inhibition of density change occurring at higher irradiances. This light-driven response was best fit with a negative exponential function including inhibition. The rate of density change in the dark was expressed as a linear function of the initial density of the cells prior to dark initiation (Visser et al. 1997). The final empirically derived model of carbohydrate ballasting was that of Wallace \& Hamilton (1999). In their study, the authors observed that the density change response of $M$. aeruginosa was quite similar to that determined by Kromkamp \& Walsby (1990) for Oscillatoria aghardii. Considering that multiple cyanobacterial species have been shown to exhibit similar density change responses to irradiance and that carbohydrate ballasting has been confirmed for Trichodesmium spp. (Villareal \& Carpenter 1990, 2003), we propose to adopt the general structure of these limnological models to explore vertical migration and the possibility for Pmining by Trichodesmium spp. in the NPSG. 


\section{MODEL DESCRIPTION AND ASSUMPTIONS}

Previous models describing the rate of density change by gas-vacuolate cyanobacteria indicate that the functional response to irradiance can be modeled with either a rectangular hyperbola assuming no photoinhibition (Kromkamp \& Walsby 1990) or a negative exponential function including photoinhibition (Visser et al. 1997). Both of these models are based upon empirical data showing that density increases are driven by photosynthesis; thus, the shape of these functions mirrors generalized models of photosynthesis $(P)$ versus irradiance $(E)$. Given that the density response of Trichodesmium spp. has not been determined, we suggest that any $P$ vs. $E$ relationship shown to be applicable to Trichodesmium colonies should be a valid first approximation for light-driven density change by this oceanic cyanobacterium. LaRoche \& Breitbarth (2005) have summarized the physiological literature regarding Trichodesmium and noted that only 4 studies (e.g. Li et al. 1980, Lewis et al. 1988, Kana 1993, Roenneberg \& Carpenter 1993) have characterized the relationship between Trichodesmium photosynthetic rates and photon flux density. While a few studies have observed photoinhibition at moderate irradiances (e.g. Li et al. 1980, photoinhibition detected at $E>500 \mu \mathrm{mol}$ photons $\mathrm{m}^{-2} \mathrm{~s}^{-1}$ ), the predominant finding has been that Trichodesmium colonies are able to tolerate high irradiances (up to $2700 \mu \mathrm{mol}$ photons $\mathrm{m}^{-2} \mathrm{~s}^{-1}$ ) without apparent signs of photoinhibition (e.g. Lewis et al. 1988, Kana 1993, Carpenter \& Roenneberg 1995). Considering these observations, we have chosen to utilize a negative exponential model (similar to Platt et al. 1980) to model the light-driven rate of density change by Trichodesmium. This model was chosen for the reason that (1) it has been shown to apply to the photosynthetic response of natural populations of colonies (Lewis et al. 1988), (2) it is consistent with previous models of density change in gas-vacuolate cyanobacteria, and (3) it can be parameterized to disregard or consider photoinhibition.

The equation for the temporal rate of density change by a single Trichodesmium colony (Eq. 1) is then written as:

$\frac{\mathrm{d} \rho_{\mathrm{c}}}{\mathrm{d} t}=c_{1} \cdot\left(1-\mathrm{e}^{-\mathrm{PAR}_{z} m / c_{1}}\right) \cdot \mathrm{e}^{-\beta \mathrm{PAR}_{z} m / c_{1}}-\left(c_{2} E_{\mathrm{a}}\right)-c_{3}$

where the first term represents the light-driven rate of density change and is a function of a rate coefficient describing the maximal rate of density increase $\left(c_{1}\right)$, the initial slope of the density-response curve $(m)$, a photoinhibition parameter $(\beta)$ and incident photosynthetically active radiation (PAR) at the depth $z$ of the colony $\left(\mathrm{PAR}_{z}\right)$. The rate of density change over time reflects the accumulation and degradation of excess carbohydrate density and is most sensitive to changes in $c_{1}$ and $m$, by nature of the prescribed functionality. The coefficient $C_{2}$ describes the relationship between the integrated value of irradiance accumulated since dawn, $E_{\mathrm{a}}$ (as per Kromkamp \& Walsby 1990), and density loss. The constant $C_{3}$ represents the minimal rate of density loss due to the basal metabolism of carbohydrates. This loss term is independent of irradiance.

The daily cycle of PAR reaching the sea surface $\left(\mathrm{PAR}_{0}\right)$ at Stn ALOHA (latitude $=22^{\circ} 45^{\prime} \mathrm{N}$ ) is calculated following the classical astronomical formula of Brock (1981) employing the correction of the solar constant by Duffie \& Beckman (1980). All model runs begin on July 1, 2005, such that solar forcing is consistent with summer fluxes of irradiance. Cloud-free days are assumed. $\mathrm{PAR}_{z}$ is calculated according to the Beer-Lambert law (Eq. 2) using a vertical attenuation coefficient $\left(k_{\mathrm{PAR}}=0.04 \mathrm{~m}^{-1}\right.$ as per Letelier et al. 2004) appropriate for Stn ALOHA:

$$
\operatorname{PAR}_{z}=\mathrm{PAR}_{0} \cdot \mathrm{e}^{-k \mathrm{PAR} \cdot z}
$$

During periods of darkness, the first term of Eq. (1) goes to 0 and the rate of density change becomes a combination of a linear light history term $\left(C_{2} \cdot E_{\mathrm{a}}\right)$ and a constant loss term $\left(C_{3}\right)$. These terms follow the formulation of Kromkamp \& Walsby (1990), given that there is no data with which to determine the specific dark period density response of Trichodesmium.

Vertical velocity. Once the density of the colony has been calculated, Stokes's Law is applied to estimate sinking or rising velocity $(\mathrm{V})$ (Eq. 3). This calculation is dependent on gravitational acceleration $(g)$, the effective colony radius $(r)$, the difference between the density of the colony $\left(\rho_{c}\right)$ and the density of seawater $\left(\rho_{w}\right)$, the molecular viscosity of the medium $(\eta)$, the ratio of cell volume to colony volume $(A)$ and a coefficient of form resistance $(\phi)$. Values or ranges for each of these parameters are listed in Table 1 . The chosen value of $A$ is specific to the near-spherical colony shape of Trichodesmium thiebautii (the so-called puff morphology). Water column density $\left(\rho_{\mathrm{w}}\right)$ structure is derived from the density profiles collected during the summer of 2004 at Stn ALOHA (Fig. 1).

$$
V=\frac{2}{9} g r^{2}\left(\rho_{\mathrm{C}}-\rho_{\mathrm{w}}\right) A /(\phi \eta)
$$

Colony density $\left(\rho_{c}\right)$ is constrained by minimum $\left(\rho_{\min }\right)$ and maximum density $\left(\rho_{\max }\right)$ values. The range for these parameters reported in the literature, a reference parameter set chosen to apply to Trichodesmium, and the range of values used for a sensitivity analysis are presented in Table 2.

Model assumptions. This model does not include Trichodesmium growth, nutrient uptake, or loss pro- 
Table 1. Parameter values for Stokes's law

\begin{tabular}{|c|c|c|c|c|}
\hline Parameter & Definition & Parameter range & Units & Source \\
\hline$r$ & Colony radius & Up to 2500 & $\mu \mathrm{m}$ & Capone et al. $(1997)^{b}$ \\
\hline$g$ & Gravitational acceleration & 9.8 & $\mathrm{~m} \mathrm{~s}^{-2}$ & Crowell (1998) \\
\hline$\rho_{\mathrm{c}}$ & Trichodesmium colony density & Variable & $\mathrm{kg} \mathrm{m}^{-3}$ & See Table 3 for ranges \\
\hline$\rho_{\mathrm{w}}$ & Seawater density $^{\mathrm{a}}$ & Variable & $\mathrm{kg} \mathrm{m}^{-3}$ & See Fig. 1 \\
\hline$\eta$ & Dynamic viscosity & $9.60 \times 10^{-4}$ & $\mathrm{~kg} \mathrm{~m}^{-1} \mathrm{~s}^{-1}$ & Sverdrup et al. (1946) \\
\hline$A$ & Cell volume colony volume $\mathrm{e}^{-1}$ & 0.05 & & Kromkamp \& Walsby (1992) \\
\hline$\phi$ & Form resistance & 1 & & Kromkamp \& Walsby $(1992)^{b}$ \\
\hline
\end{tabular}

cesses, rather the only physiological processes that are considered are the light-driven rates of accumulation and degradation of excess carbohydrate density. Given the lack of empirical information regarding rates of density change by Trichodesmium in response to environmental parameters, we have utilized a wide range of parameter space. Perhaps the greatest sources of error inherent in our model formulation are that (1) we have considered the effects of physical forcing to be negligible, and (2) we have assumed that the only variable biomolecular component of the cell affecting density is carbohydrates. In regards to the first point,

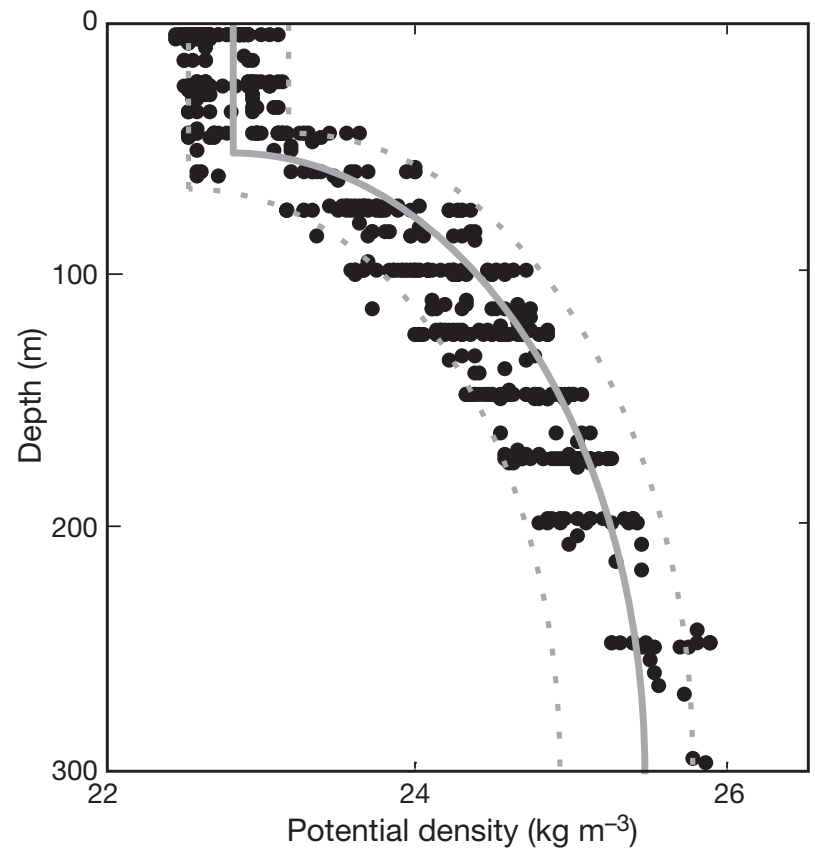

Fig. 1. Stn ALOHA water column density structure. Data taken from HOT cruises 159 to 163 (May to October 2004). Data are fit to a piecewise model (solid grey line) where potential density is constant (22.854) in the upper $45 \mathrm{~m}$ and determined with a 4 th degree polynomial fit to the centered and scaled data set for depths $>45 \mathrm{~m}$. The dotted grey lines show the upper and lower envelope of the data. For the lower range, the mixed layer depth is extended to $60 \mathrm{~m}$ while the upper range mixed layer depth is $40 \mathrm{~m}$
Trichodesmium spp. typically bloom under calm, stratified conditions, suggesting that our results are valid when applied to summer populations. Secondly, intracellular concentrations of other biomolecules (e.g. proteins, lipid, polyphosphate) and the nutritional history and composition of the cell may also affect cell density and rates of density change (see review of Oliver 1994). While we acknowledge these points, given the quantity of data that supports light-driven carbohydrate ballasting as a mechanism of buoyancy regulation by Trichodesmium (Villareal \& Carpenter 1990, Walsby 1992, Letelier 1994), we have reduced the problem so as to present an assessment of vertical migration, as it would be driven by carbohydrate ballasting alone. This approach allows for the prediction of rates of density change, vertical colony velocities, migratory amplitudes, and depth distributions of colonies that can be compared to observations from natural populations.

\section{RESULTS}

The model was run using successive parameter combinations of $c_{1}, c_{2}, m, \beta, \rho_{\min }$ and $\rho_{\max }$, resulting in a total of 3600 unique model solutions. The range of each parameter tested is consistent with the range of empirically determined values drawn from the literature. For all of these model runs the starting depth was $5 \mathrm{~m}$, colony radius was $1500 \mu \mathrm{m}$, initial colony density was $1025 \mathrm{~kg} \mathrm{~m}^{-3}$ and the initial integrated light history $\left(E_{\mathrm{a}}\right)$ was set to $650 \mu \mathrm{mol}$ photons $\mathrm{m}^{-2}$. The parameter $C_{3}$ was held constant at $0.023 \mathrm{~kg} \mathrm{~m}^{-3} \mathrm{~min}^{-1}$; thus, the parameterizations presented here have analyzed variance of light-dependent parameters only.

Model solutions $(n=3600)$ for the full range of parameters cited in Table 2 have been sorted into 5 types (Fig. 2) based upon the following criteria applied to solutions after a $4 \mathrm{~d}$ spin-up period. A total of $59 \%$ of the model solutions result in the colony being trapped at the water surface; these solutions are classified as Type 1. Another type of solution (10\%) exhibits 
Table 2. Buoyancy Model Parameters. The model was run for successive parameter combinations, whereby each parameter range tested is consistent with the range of empirically determined values drawn from the literature. From the 3600 model solutions, a single parameter set (of Type 3), termed the P-mining solution, was chosen to represent a parameterization that would facilitate P-mining by Trichodesmium spp. in the North Pacific subtropical gyre (NPSG)

\begin{tabular}{|c|c|c|c|c|c|c|}
\hline Parameter & Definition & Units & $\begin{array}{l}\text { Literature } \\
\text { range }^{\mathrm{a}}\end{array}$ & $\begin{array}{l}\text { Parameter } \\
\text { range }\end{array}$ & $\begin{array}{l}\text { Increment } \\
\text { value }\end{array}$ & $\begin{array}{l}\text { P-mining } \\
\text { solution }\end{array}$ \\
\hline$c_{1}$ & Max. rate of density increase & $\mathrm{kg} \mathrm{m}^{-3} \min ^{-1}$ & 0.043 to 0.161 & 0.033 to 0.170 & 0.033 & 0.1 \\
\hline$C_{2}$ & $\begin{array}{l}\text { Previous light history } \\
\text { interaction term }\end{array}$ & $\begin{array}{l}\left(\mathrm{kg} \mathrm{m}^{-3} \mathrm{~min}^{-1}\right) / \\
\mu \mathrm{mol} \text { photons } \mathrm{m}^{-2} \mathrm{~s}^{-1}\end{array}$ & $\begin{array}{l}1.67 \times 10^{-5} \text { to } \\
7.67 \times 10^{-5}\end{array}$ & $\begin{array}{c}1.53 \times 10^{-5} \text { to } \\
1.38 \times 10^{-4}\end{array}$ & $6.14 \times 10^{-5}$ & $2.56 \times 10^{-5}$ \\
\hline$C_{3}$ & Min. rate of density loss & $\mathrm{kg} \mathrm{m}^{-3} \min ^{-1}$ & 0.0165 to 0.023 & 0.023 & & 0.023 \\
\hline$m$ & $\begin{array}{l}\text { Initial slope of density- } \\
\text { response curve }\end{array}$ & $\begin{array}{l}\left(\mathrm{kg} \mathrm{m}^{-3} \min ^{-1}\right) / \\
\text { بmol photons } \mathrm{m}^{-2} \mathrm{~s}^{-1}\end{array}$ & $1.6 \times 10^{-3 b}$ & $\begin{array}{l}1.76 \times 10^{-4} \text { to } \\
8.78 \times 10^{-4}\end{array}$ & $1.8 \times 10^{-4}$ & $5.27 \times 10^{-4}$ \\
\hline beta & Photoinhibition parameter & Dimensionless & None & 0 to 0.06 & 0.03 & 0.03 \\
\hline$\rho_{\min }$ & Min. colony density & $\mathrm{kg} \mathrm{m}^{-3}$ & 920 to 970 & 920 to 1010 & 30 & 950 \\
\hline$\rho_{\max }$ & Max. colony density & $\mathrm{kg} \mathrm{m}^{-3}$ & 1035 to 1065 & 1020 to 1065 & 15 & 1065 \\
\hline
\end{tabular}

colonies that return to the water column surface without becoming trapped. The maximum depth of migration for these solutions is $<85 \mathrm{~m}$; these solutions are classified as Type 2 . An additional subset of migrations $(25 \%)$ also exhibits a return to the surface without
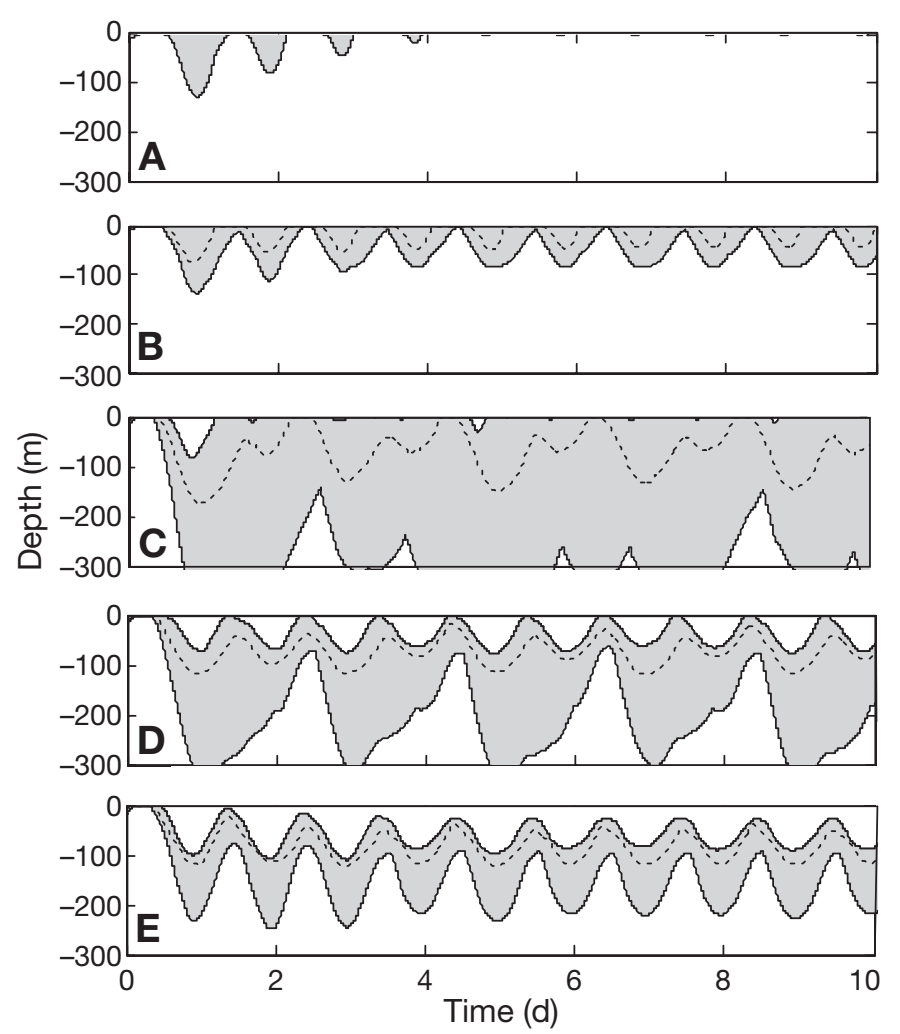

Fig. 2. Depth envelope (max. - min. depth $=$ shaded area) of colony depth vs. time for model solutions $(\mathrm{n}=3600)$ of (A) Type 1, (B) Type 2, (C) Type 3, (D) Type 4 and (E) Type 5; see 'Results' for criteria. Mean depth for each type is denoted by a dotted line. trapping. However, these colonies migrate to a maximum depth greater that $85 \mathrm{~m}$; these migrations are classified as Type 3. A number of model solutions resulted in migrations that never returned to the water column surface after the spin-up period. Of these solutions without a surface component, 5\% (of total) are characterized by migrations with a minimum depth of $<25 \mathrm{~m}$ (Type 4) and 1\% (of total) result in trapping of the colony below $25 \mathrm{~m}$ (Type 5). The ranges of parameters for each type, the characteristic rates of density change, as well as the mean and maximum depths achieved by a migrating colony (radius $=1500 \mu \mathrm{m}$ ) after a $4 \mathrm{~d}$ spin-up period are presented in Table 3 . Of the possible types of model solutions (Fig. 2), Type 3 and a portion of Type 4 solutions $(n=698)$ represent parameterizations of carbohydrate ballasting that could facilitate Trichodesmium spp. P-mining at Stn ALOHA.

Of the total number of model solutions, 698 (19.4\% of the total number of parameter combinations) led to vertical migration to the average Stn ALOHA phosphocline depth $(125 \pm 39 \mathrm{~m}$, calculated using a $0.05 \mu \mathrm{mol}$ surface offset applied to June-August Hawaii Ocean Time-series (HOT) data from 1989 to 2001; summer data are used as this is when Trichodesmium blooms are typically observed). The modeled rate of density change over time was between -0.1062 and $0.1436 \mathrm{~kg}$ $\mathrm{m}^{-3} \mathrm{~min}^{-1}$. From these solutions, we have chosen a single parameter set to illustrate the potential of P-mining. For further reference, this parameter set is termed the P-mining solution (Table 2). The rate of density change as a function of light as well as the temporal evolution of colony depth and colony velocity are shown for the P-mining solution in Fig. 3. Modeled colony velocities (Fig. 3C) are generally within the range of the velocity measured for Trichodesmium spp., i.e. $10.8 \mathrm{~m} \mathrm{~d}^{-1}$ (Walsby 1978). 
Table 3. Parameter range for the 5 types of model solutions. For all types, the parameter $c_{3}$ (min. rate of density change) is equal to 0.023 . When solutions encompassed the full range (FR) of a particular parameter, FR is noted (see Table 2). $c_{1}$ : max. rate of density change $C_{2}$ : light history interaction term; $m$ : initial slope of the density response curve; $\beta$ : photoinhibition parameter; $\rho_{\text {min }}$ : min. colony density; $\rho_{\max }$ : max. colony density. $\rho_{c}$ : Trichodesmium colony density; $t$ : time; $z$ : depth

\begin{tabular}{|ccccccccrc}
\hline Type & $\begin{array}{c}\text { Total } \\
(\%)\end{array}$ & $c_{1}$ & $C_{2}$ & $\begin{array}{c}m \\
\left(10^{-4}\right)\end{array}$ & $\beta$ & $\rho_{\text {min }}$ & $\rho_{\text {max }}$ & $\begin{array}{c}\Delta \rho_{\mathrm{c}} \Delta t^{-1} \\
\left(\mathrm{~kg} \mathrm{~m}^{-3} \mathrm{~min}^{-1}\right)\end{array}$ \\
\hline $1^{\mathrm{a}}$ & 59 & FR & FR & FR & FR & FR & 1020 to 1065 & -0.121 to 0.144 \\
$2^{\mathrm{b}}$ & 10 & 0.07 to 0.17 & FR & FR & FR & FR & 1035 to 1065 & -0.121 to 0.144 & $0.02 \pm 0.2$ \\
$3^{\mathrm{c}}$ & 25 & 0.07 to 0.18 & FR & FR & FR & FR & 1035 to 1065 & -0.116 to 0.144 & $176.9 \pm 23.8$ \\
$4^{\mathrm{d}}$ & 5 & 0.07 to 0.19 & FR & FR & FR & FR & 1035 to 1065 & -0.073 to 0.137 & $123.1 \pm 25.6$ \\
$5^{\text {e }}$ & 1 & 0.10 to 0.17 & FR & 5.3 to 8.8 & FR & FR & 1035 to 1065 & -0.046 to 0.119 & $129.5 \pm 7.8$
\end{tabular}

${ }^{\mathrm{a}}$ Max. depth $=0 \mathrm{~m}_{i}{ }^{\mathrm{b}} \mathrm{min}$. depth $=0 \mathrm{~m}$, max. depth $<85 \mathrm{~m}^{\mathrm{c}}{ }^{\mathrm{c}} \min$. depth $=0 \mathrm{~m}$, max. depth $>85 \mathrm{~m}_{i}{ }^{\mathrm{d}} 0 \mathrm{~m}>\min$. depth $<25 \mathrm{~m}$; emin. depth $>25 \mathrm{~m}$

The impact of colony size upon the mean and maximum depth of the P-mining solution is shown in Fig. 4. This analysis suggests that a colony would need to be approximately $1000 \mu \mathrm{m}$ in radius to reach the average position of the phosphocline during summer conditions at Stn ALOHA. It should be noted that the maximum depth achieved by a colony does not increase steadily as a function of colony radius, rather there are values of increasing colony size that result in a shallower maximum depth (e.g. as observed between 1900 and $2000 \mu \mathrm{m})$. This effect is a consequence of colonies having variable light history, whereas the larger colony does not spend enough time in surface waters to incur the photon fluxes that would be required to generate migrations to a depth greater than that of a smaller colony (i.e. values for $E_{\mathrm{a}}$ remain relatively low so that the larger colony will not return to the surface, thus prohibiting large rates of ballast increase and limiting the maximum depth of migration).

The effect of alterations in water column density structure is presented in Fig. 5, whereas the model was run using the upper and lower envelope of the data as well as the mean water column density fit derived from Fig. 1. The major impact of these alterations in water column density structure is a change in the timing of migrations. We have also examined the model solution (using the P-mining parameter set) for a $150 \mathrm{~d}$ runtime in order to assess the potential impact of
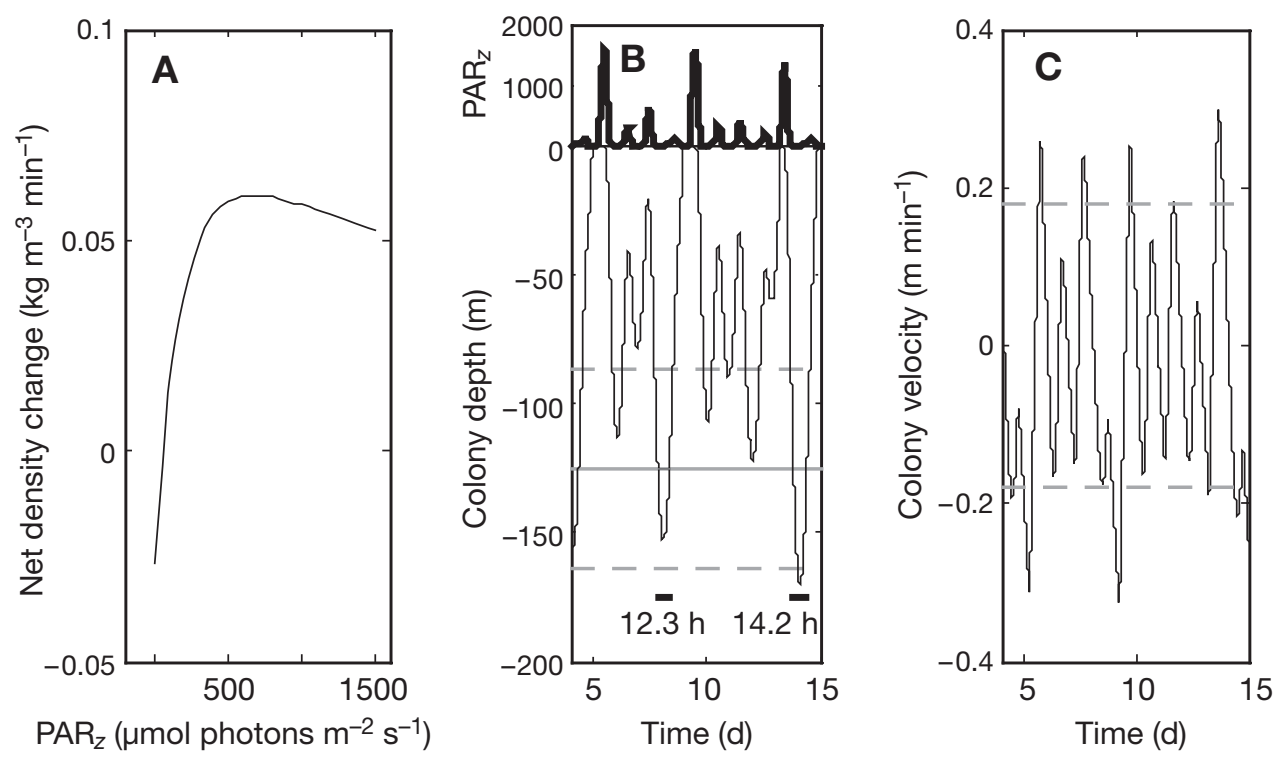

Fig. 3. P-mining solution showing (A) the net rate of density change as a function of the photosynthetically active radiation intensity at the depth of the colony $\left(\mathrm{PAR}_{z}\right)$; (B) the temporal evolution of colony depth for a $10 \mathrm{~d}$ period relative to $\mathrm{PAR}_{z i}$ and $(\mathrm{C})$ the vertical velocity of the colony over this same period. For this model run, as with all of the previous runs, the starting depth was $5 \mathrm{~m}$, colony radius was $1500 \mu \mathrm{m}$, and the initial density of the colony was $1025 \mathrm{~kg} \mathrm{~m}^{-3}$. Solid line in (B) represents the mean summertime (June to August) phosphocline depth $(125 \mathrm{~m})$ at Stn ALOHA calculated using a $0.05 \mu \mathrm{mol} \mathrm{l}^{-1}$ surface offset. Dashed lines indicate $\pm \mathrm{SD}(38.7 \mathrm{~m})$. The duration of 2 sections of the migration where depth was greater than $125 \mathrm{~m}$ are noted in $(\mathrm{B})$. Dashed lines in $(\mathrm{C})$ represent the maximum vertical velocity recorded for a Trichodesmium colony $\left(0.18 \mathrm{~m} \mathrm{~min}^{-1}\right.$; Walsby 1978$)$ 


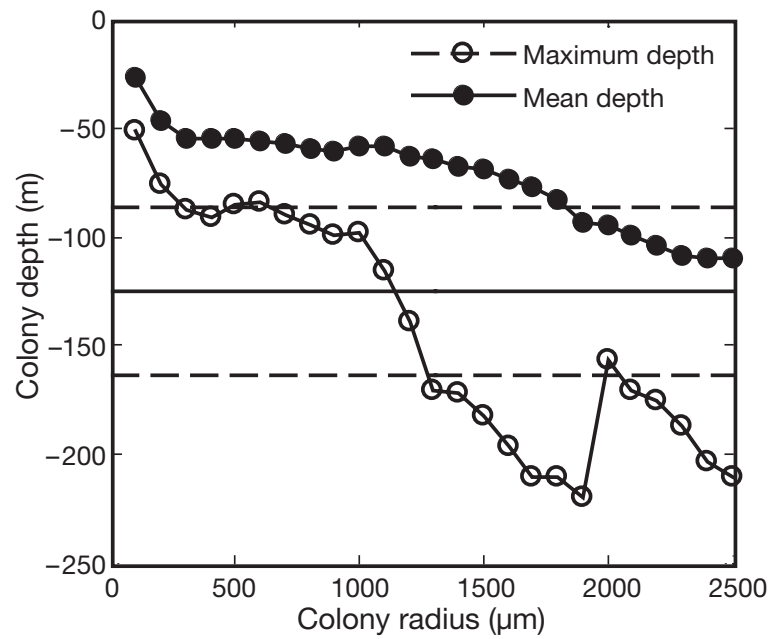

Fig. 4. The consequences of varying colony size, using the P-mining parameter set, are shown for colony radii of 100 to $2500 \mu \mathrm{m}$. These results present the mean and max. depths achieved by colonies of variable size over a $15 \mathrm{~d}$ model run, allowing for a $4 \mathrm{~d}$ spin-up. Solid line represents the mean summertime (June to August) phosphocline depth $(125 \mathrm{~m})$ at Stn ALOHA. Dashed lines indicate the mean $\pm 1 \mathrm{SD}(38.7 \mathrm{~m})$. The nonlinearity observed in the max. depth trend reflects the effect of variable light history (see 'Results')

the seasonal cycle of incoming irradiance upon migrations. Results indicate that the maximum depth of migration decreases by $\sim 50 \mathrm{~m}$ in response to a decrease in $\mathrm{PAR}_{0}$ as the season turns to winter (results not shown).

Additionally, this model has been run with randomized initial conditions in order to simulate a population of colonies with variable buoyancy characteristics. Specifically, 5000 colonies were assigned a randomly generated colony radius between 50 and $1500 \mu \mathrm{m}$, a starting depth between 5 and $85 \mathrm{~m}$, an initial colony density between $\rho_{\min }$ and $\rho_{\max }$ and initial $E_{\mathrm{a}}$ in the range of 0 to $650 \mu \mathrm{mol}$ photons $\mathrm{m}^{-2} \mathrm{~s}^{-1}$. The model was then run for a $15 \mathrm{~d}$ period using parameterizations typical of Type 2, 3, and 4 model solutions. Type 2 and 4 parameters are as follows: $c_{1}=0.1$ (Type 2 and 4$)_{i}$ $C_{2}=1.38 \times 10^{-4}($ Type 2$)$ and $1.54 \times 10^{-5}($ Type 4$) ; C_{3}=$ 0.023 (Type 2 and 4 ),$m=5.3 \times 10^{-4}$ (Type 2) and $7.02 \times$ $10^{-4}$ (Type 4$), \beta=0.03$ (Type 2) and 0.0 (Type 4$), \rho_{\min }=$ 950 (Type 2) and 1020 (Type 4), $\rho_{\max }=1065$ (Type 2) and 1035 (Type 4). The P-mining solution parameters were used for Type 3 runs (Table 2). A random day was chosen from each run and the depth of each of the 5000 colonies was binned into $10 \mathrm{~m}$ intervals with a timestep of 5 min. Fig. 6 represents the modeled depth distribution at each time-step $(\mathrm{n}=288)$ over the course of $1 \mathrm{~d}$ compared to the actual distribution of colonies collected between April and September of 1989-1992 at Stn ALOHA (Letelier 1994). The average depth of the mixed layer during summer ( $45 \mathrm{~m}$; Letelier 2004) and the phosphocline $(125 \mathrm{~m})$ are shown in Fig. 6 for refer-
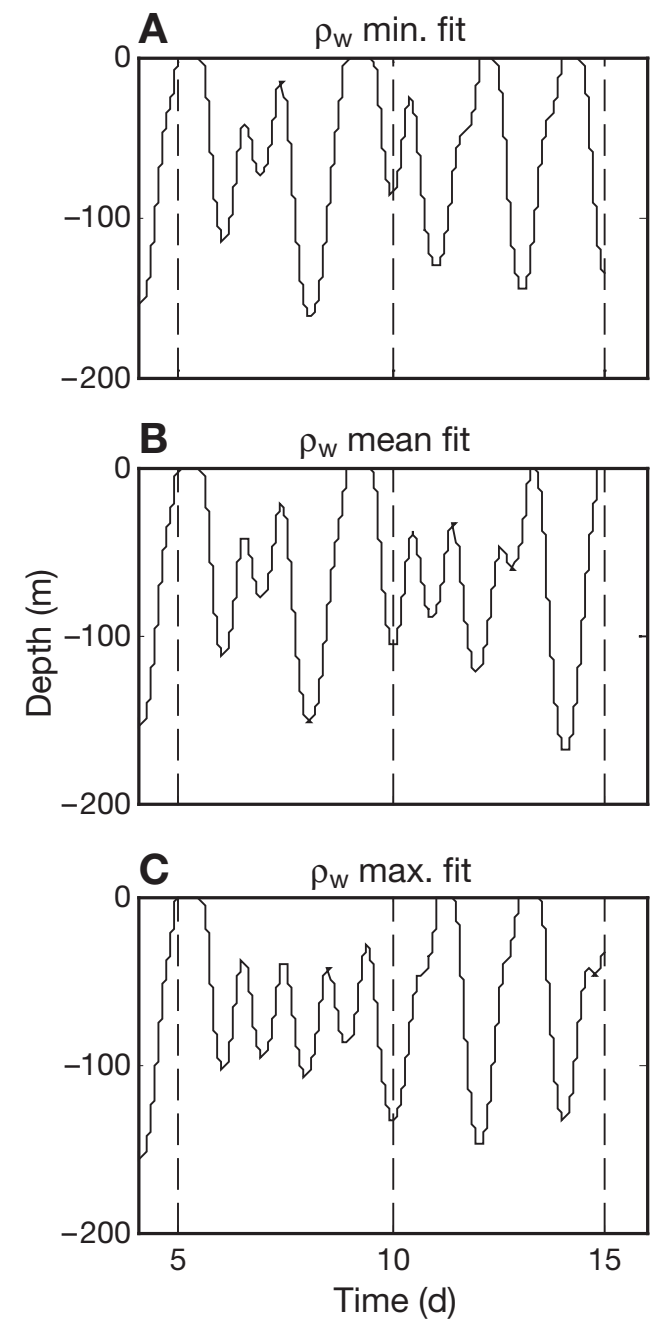

Fig. 5. The major impact of alterations in water column density $\left(\rho_{\mathrm{w}}\right)$ structure is a change in the timing of migrations. Density alterations have little effect on the maximum penetration depth of a colony. Colony depth over time is shown for model runs using the lower envelope of (A) $\rho_{\mathrm{wi}}$ (B) mean $\rho_{\mathrm{w}}$ fit; and (C) upper envelope of $\rho_{\mathrm{w}}$

ence. The range of colony concentration at each depth represents the spectrum of colony density that would be encountered over the course of $1 \mathrm{~d}$ of sampling. These results indicate that vertically migrating cells may accumulate in discrete depth maxima and that the vertical position of these maxima will change over the course of the day.

\section{DISCUSSION}

A common paradigm pertaining to cyanobacteria is that buoyancy regulation may be a physiological adaptation to exploit the separation of light and nutrients (Walsby \& Reynolds 1980, Oliver 1994, Pearre 2003). However, this paradigm has been developed for mostly 


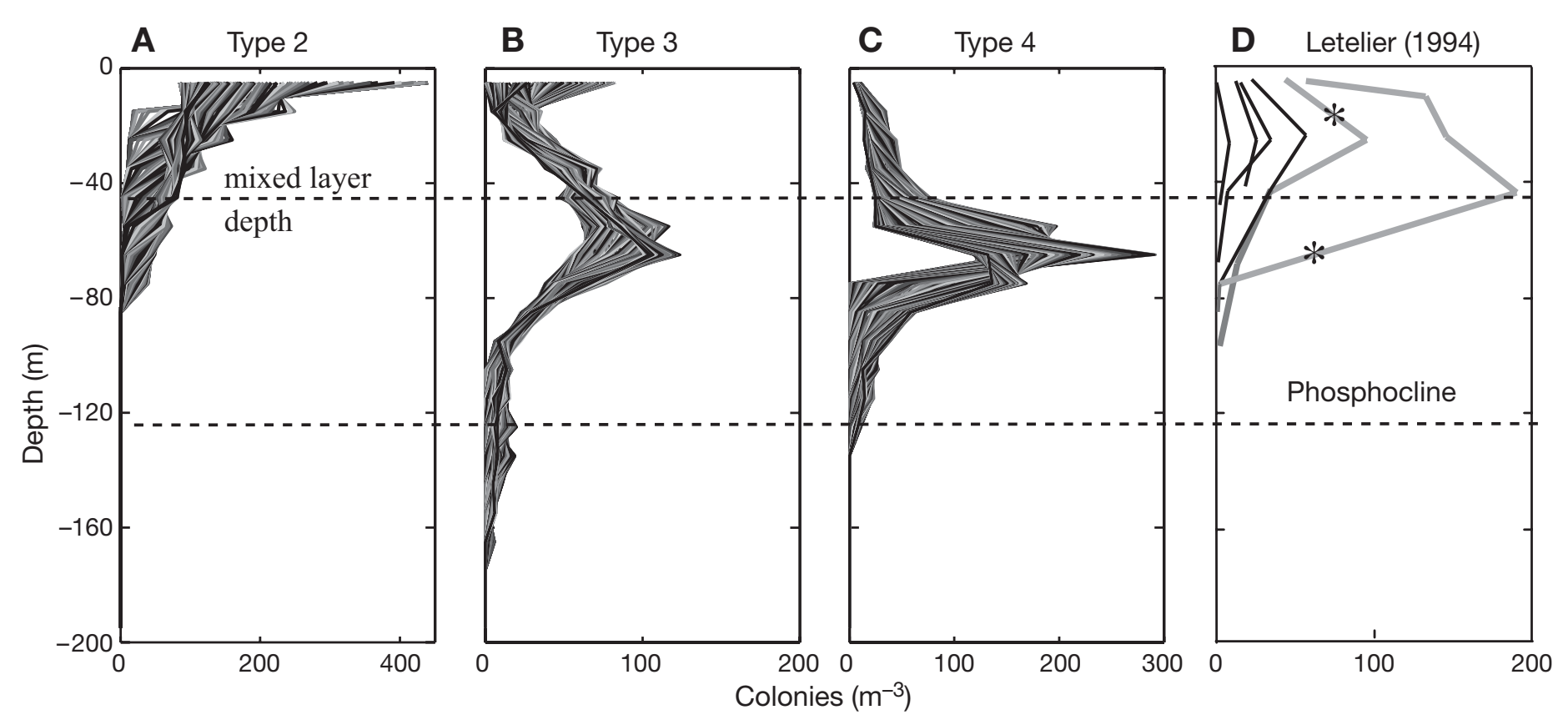

Fig. 6. Comparison of the actual depth distribution of NPSG Trichodesmium colonies collected during the months of April through September, 1989 to 1992 (Letelier 1994) and the modeled depth distribution of 5000 colonies of random size having randomized initial conditions and parameters consistent with (A) Type 2, (B) Type 3, and (C) Type 4 model solutions (see 'Results' for additional run conditions). Model colonies were binned in $10 \mathrm{~m}$ intervals and resultant depth profiles of colonies at 5 min intervals over $1 \mathrm{~d}(\mathrm{n}=288)$ are plotted for each model type. The range of colonies per $\mathrm{m}^{3}$ at each depth then presents the span of colony density that would be encountered over the course of $1 \mathrm{~d}$. Dashed lines denote the mean mixed layer depth (MLD, $45 \mathrm{~m}$ ) and phosphocline depth (125 m). Observed colony profiles consistent with P-mining are in grey and noted with an asterisk in (D)

limnological systems where the depth of the nutricline is significantly less than that observed in oligotrophic oceanic habitats such as the NPSG. Given this implied constraint, questions have been raised regarding whether or not it is feasible for oceanic cyanobacteria to conduct the $>100 \mathrm{~m}$ migrations that would be required to mine for P in the NPSG (see Villareal \& Carpenter 2003). While migrations of this scale, accompanied by nutrient shuttling have been confirmed in the NPSG for large mats of the diatom Rhizosolenia (Villareal et al. 1993, Richardson \& Cullen 1998) only ancillary data exist for NPSG Trichodesmium spp. populations (Letelier 1994). To investigate this possibility, we have constructed a numerical model of Trichodesmium carbohydrate ballasting-mediated vertical migration, based upon existing empirical models developed and validated for other cyanobacterial genera. We have applied our results to an analysis of the ecological significance of vertical migration by natural populations of Trichodesmium colonies.

Of the 3600 parameter combinations tested, the numerically dominant type of solution was not P-mining, but rather trapping of the colony at the water surface. This type of solution occurred as a consequence of low rates of ballast accumulation $\left(\leq 0.066 \mathrm{~kg} \mathrm{~m}^{-3}\right.$ $\mathrm{min}^{-1}$ ) resulting in shallower initial migrations and higher rates of ballast respiration occurring in response to a high-irradiance light history (high $E_{\mathrm{a}}$ ). The remaining fraction of these surface-trapped solutions occurred as a result of limitation of the maximum colony density to a value $\left(\rho_{\max }=1020\right)$ that prohibited the colony from accumulating sufficient ballast to escape the surface. Observation of this type of solution is consistent with the findings by Kromkamp \& Walsby (1992) and Clayton (2001), who have also described surface-trapped model simulations for Trichodesmium spp. Kromkamp \& Walsby (1992) hypothesized that this type of model solution would result as energy generated by photosynthesis is used to fuel nitrogen fixation, thus effectively reducing rates of ballast accumulation. In contrast, Clayton (2001) has proposed that surface-trapping of populations would occur following prolonged periods of water column mixing where decreased irradiance fluxes would result in lower carbohydrate accumulation rates. As mixing is relaxed, these low-density colonies would rapidly rise to the ocean surface, forming accumulations. Surface accumulations may also be generated by temperaturedriven increases in respiration, expressed as an increase in $C_{3}$ in this model. In addition to lowered net carbohydrate accumulation rates, our model predicts that limitation of the carbohydrate storage capacity of the cell (expressed as lowered $\rho_{\max }$ ) could also result in surface accumulations. Each of these hypotheses is 
independent of whether or not the surface population subsequently experiences de novo growth, i.e. blooms. Experimental determination of the range of deballasting rates specific to Trichodesmium spp. as well as the boundaries of cell density $\left(\rho_{\min }, \rho_{\max }\right)$ under different conditions (i.e. low light, high temperature, etc.) can be compared to the data presented herein in order to further explore hypotheses regarding the formation of surface blooms, undoubtedly a defining characteristic of Trichodesmium autoecology.

A considerable percentage $(19.4 \%)$ of the model solutions (of Type 3 and Type 4 solutions) are consistent with P-mining by Trichodesmium, such that the maximum depth of migration is $\geq 125 \mathrm{~m}$. The range of net density change over time for P-mining solutions was between -0.1062 and $0.1436 \mathrm{~kg} \mathrm{~m}^{-3} \mathrm{~min}^{-1}$. These parameters represent numerical constraints for the rate of density change that would be required to facilitate Pmining in the NPSG. Further analyses of these results indicate that the observed summertime fluctuations in water column density at Stn ALOHA should have little effect on this maximum migration depth (Fig. 5). In contrast, colony size significantly impacts model solutions. For P-mining solutions specifically, results suggest that colonies must be on the order of $\sim 1000 \mu \mathrm{m}$ in radius in order to penetrate the average depth of the phosphocline (Fig. 4). Colonies of up this size and larger (i.e. 1000 to $2500 \mu \mathrm{m}$ in radius; Capone et al. 1997) have been observed in nature. However, neither the frequency of occurrence nor the relative size distributions of natural populations is known. This sensitivity highlights the need for information regarding the morphological distribution of Trichodesmium populations. For the NPSG, Letelier et al. (1998) reports that the colonial morphology accounts for $12 \%$ of Trichodesmium biomass with free filaments comprising the remaining fraction of the population. Neither the size distribution nor the relative shapes (e.g. fusiform, near-spherical) of these colonies has been determined. This information will be essential to an evaluation of the achievable vertical velocities of natural populations. Nonetheless, we can speculate that the size distribution of Trichodesmium spp. colonies would be variable in time. In this case, colony formation and growth itself may facilitate P-mining; such that colonies may only become vectors for the upward flux of $\mathrm{P}$ once they reach a critical size (e.g. $>1000 \mu \mathrm{m}$ for near-spherical forms).

P-mining by Trichodesmium spp. may act as a purely biological means of transporting $\mathrm{P}$ from below the phosphocline into the surface mixed layer, thereby fueling net export. This behavior may also serve to supplement P-requirements for growth. We can approximate these potential P-fluxes by combining results from this model with published rates of colony abundance, P-uptake and P-export. Using the P-mining solution as an example, our model predicts that a migrating colony would spend up to $14 \mathrm{~h}$ below the average depth of the phosphocline, nearly all of which time the colony would be in the dark (see Fig. 3). Using the mean ${ }^{32} \mathrm{PO}_{4}{ }^{-3}$ dark period uptake rate of $0.09 \mathrm{nmol}$ $\mathrm{P}_{\text {colony }}{ }^{-1} \mathrm{~h}^{-1}$ reported by Letelier (1994), we estimate that a migrating colony would consume up to $1.3 \mathrm{nmol}$ $\mathrm{P}$ per migration to the phosphocline. Given the mean P quotas exhibited by NPSG populations of Trichodesmium (0.91 nmol P colony ${ }^{-1}$; White et al. 2006), an individual colony could potentially fulfill its entire P-quota during the 12 to $14 \mathrm{~h}$ spent below the phosphocline. If we then assume that the depth-integrated concentration of colonies that are able to conduct these migrations is large (2000 colonies $\mathrm{m}^{-2}$; see Fig. 4 for reference) and that phosphocline scale migrations occur with a frequency of $0.5 \mathrm{~d}^{-1}$ (Fig. 3), we calculate that P-mining by Trichodesmium spp. could result in P-inputs to the upper mixed layer that would be equivalent to as much as $10 \%$ of the mean P-based export flux measured at $150 \mathrm{~m}\left(400 \mathrm{\mu g} \mathrm{m}^{-2} \mathrm{~d}^{-1}\right)$. While these back-of-the-envelope calculations illustrate the potential for P-mining by Trichodesmium spp. to supplement P-requirements for growth and fuel P-based export, the magnitude of our estimates should be considered upper limits given that we have not considered biomass loss terms.

P-mining is but one predicted type of migration. It may be the case that colony migrations at Stn ALOHA more closely match another one of the migration types (i.e. Types 1 to 4 ) presented here. Speculatively, if the light-driven density response of natural Trichodesmium populations were similar to one of the migration types that we described, we would expect that this population would exhibit a depth distribution that would also be consistent with model predictions for that type of migration. In order to explore this further, we have compared (Fig. 6) the depth distribution of 5000 colonies of randomly generated colony size and variable initial conditions having parameters typical of Types 2, 3, and 4 model solutions to the actual depth distribution of Trichodesmium colonies collected during April through September of 1989-1992 (Letelier 1994). Specifically, modeled distributions simulate mixed populations of colonies of variable size having a wide range of starting depths, previous irradiance history and initial colony densities with parameters for the rate of density change typical of a single migration type. Comparison of the modeled distributions from each Type $(2,3$, or 4$)$ indicates that Type 2 migrations are most consistent with actual colony profiles such that these profiles consist of colonies generally occurring above the surface mixed layer depth. There are a fewer number of observed colony profiles (marked with an asterisk in Fig. 6) where a substantial fraction 
of the population occurs below the mixed layer. These profiles are generally coherent with the depth distributions that would result from simulated migrations where a fraction of colonies would be capable of Pmining (Types 3 and 4). Types 3 and 4 distributions, however, appear to overestimate colony abundance in deep layers, suggesting that in nature a smaller fraction of the population would be of the radius required (e.g. $1100 \mu \mathrm{m}$ for near-spherical colonies) to shuttle P from depth than was randomly generated in our model runs. Regardless of the type of migration simulated, model results indicate that sampling time should have a strong impact upon the perceived depth distributions of natural populations. Given the migratory capacity of Trichodesmium, sampling should be conducted at multiple times throughout the day and night and at multiple depths in order to accurately estimate the range of Trichodesmium colony profiles.

In conclusion, the output from this model suggests a range of net density change and colony profiles that can be compared to laboratory and field observations in order to more closely constrain the ecological importance of vertical migration by Trichodesmium. It should be cautioned, however, that while we have assumed that the timing of vertical migration is related to the light cycle in a diel sense, this does not explicitly imply that migrations occur daily; rather some stimulus may be necessary to drive carbohydrate ballasting. We have already discussed the potential of colony growth in relation to the amplitude of vertical migration; nutrient restriction of growth is another potential means by which the density response of the cell may be altered. It is well documented that nutrient limitation may result in increased carbohydrate accumulation rates (Oliver 1994). The progression of nutrient stress may then lead to the initiation of larger amplitude migrations by nutrient limited colonies, potentially resulting in P-mining.

It should also be noted that while the primary focus of this modeling effort has been an assessment of Pmining, it is likely that vertical migration may serve numerous functions. Specifically, vertical migration should provide a competitive advantage to migrating versus nonmigrating colonies (of the same size), as movement alone, whether up or down, should enhance P-diffusion close to the cell wall and facilitate increased P-uptake relative to nonmigrating colonies. Particularly for large colonies, movement may be an effective means to offset the disadvantage of a high surface area to volume ratio. Buoyancy regulation may also allow cells to escape potentially damaging photon fluxes. Following parameter calibration with observations, inclusion of this simple model into $1 \mathrm{D}$ and 3D models should allow for better simulations of the vertical distribution of Trichodesmium biomass and thus better representations of Trichodesmium productivity.
Acknowledgements. Support for this project was provided by PARADIGM 032002-535495 (A.E.W./Y.H.S.) and NSF OCE03-26616 (R.M.L./A.E.W.). David M. Karl provided helpful discussion and critique.

\section{LITERATURE CITED}

Bowman TE, Lancaster LJ (1965) A bloom of the planktonic blue-green algae, Trichodesmium erythraeum, in the Tonga Islands. Limnol Oceanogr 10:291-293

Brock C (1981) Calculating solar radiation for ecological studies. Ecol Model 14:1-19

Capone DG (2001) Marine nitrogen fixation: What's the fuss? Curr Opin Microbiol 4:341-348

Capone DG, Zehr JP, Paerl HW, Bergman B, Carpenter EJ (1997) Trichodesmium, a globally significant marine cyanobacterium. Science 276:1221-1229

Capone DG, Subramaniam A, Montoya JP, Voss M, Humborg C, Johansen AM, Siefert RL, Carpenter EJ (1998) An extensive bloom of the $\mathrm{N}_{2}$-fixing cyanobacterium Trichodesmium erythraeum in the central Arabian Sea. Mar Ecol Prog Ser 172:281-292

Carpenter EJ, Roenneberg T (1995) The marine planktonic cyanobacteria Trichodesmium spp.: photosynthetic rate measurement in the SW Atlantic Ocean. Mar Ecol Prog Ser 118:267-273

Carpenter EJ, Subramaniam A, Capone DG (2004) Biomass and primary productivity of the cyanobacterium Trichodesmium spp. in the tropical N Atlantic Ocean. Deep-Sea Res 51:173-203

Clayton TD (2001) Trichodesmium spp.: numerical studies of resource competition, carbohydrate ballasting and remotesensing reflectance. PhD dissertation, Old Dominion University, Norfolk, VA

Crowell B (1998) Newtonian physics. Light and Matter. www.lightandmatter.com

Duffie JA, Beckman WA (1980) Solar engineering of thermal processes. Wiley, New York

Kana TM (1993) Rapid oxygen cycling in Trichodesmium thiebautii. Limnol Oceanogr 38:18-24

Karl DM, Letelier RM, Hebel DV, Bird DF, Winn CD (1992) Trichodesmium blooms and new nitrogen in the North Pacific gyre. In: Carpenter EJ, Capone DG, Rueter JG (eds) Marine pelagic Cyanobacteria: Trichodesmium and other diazotrophs. Kluwer Academic Publishers, Norwell, MA, p 219-237

Karl DM, Michaels A, Bergman B, Capone DG, and 6 others (2002) Dinitrogen fixation in the world's oceans. Biogeochemistry 57/58:47-98

Kromkamp J, Walsby AE (1990) A computer model of buoyancy and vertical migration in cyanobacteria. J Plankton Res 12:161-183

Kromkamp J, Walsby AE (1992) Buoyancy regulation vertical migration of Trichodesmium: a computer model prediction. In: Carpenter EJ, Capone DG, Rueter JG (eds) Marine pelagic Cyanobacteria: Trichodesmium and other diazotrophs. Kluwer Academic Publishers, Norwell, MA, p 219-237

LaRoche J, Breitbarth E (2005) Importance of the diazotrophs as a source of new nitrogen in the ocean. J Sea Res 53:67-91

Letelier RM (1994) Studies on the ecology of Trichodesmium spp. (Cyanophyceae) in the central North Pacific gyre. $\mathrm{PhD}$ dissertation, University of Hawaii, Manoa, HI

Letelier RM, Karl DM (1998) Trichodesmium spp. physiology and nutrient fluxes in the North Pacific subtropical gyre. Aquat Microb Ecol 15:265-276 
Letelier RM, Karl DM, Abbott MR, Bidigare RB (2004) Light driven seasonal patterns of chlorophyll and nitrate in the lower euphotic zone of the North Pacific Subtropical Gyre. Limnol Oceanogr 49:508-519

Lewis MR, Ulloa O, Platt T (1988) Photosynthetic action, absorption, and quantum yield spectra for a natural population of Oscillatoria in the North Atlantic. Limnol Oceanogr 33:92-98

Li WKW, Glover HE, Morris I (1980) Physiology of carbon photoassimilation by Oscillatoria thiebautii in the Caribbean Sea. Limnol Oceanogr 25:447-456

Mulholland MR, Capone DG (2001) Stoichiometry of nitrogen and carbon utilization in cultured populations of Trichodesmium IMS101: Implications for growth. Limnol Oceanogr 46:436-443

Oliver RL (1994) Floating and sinking in gas-vacuolate cyanobacteria J Phycol 30:161-173

Pearre S Jr (2003) Eat and run? The hunger/satiation hypothesis in vertical migration: history, evidence and consequences. Biol Rev 78:1-79

Platt TC, Gallegos I, Harrison WG (1980) Photoinhibition of photosynthesis in natural assemblages of marine phytoplankton. J Mar Res 38:687-701

Richardson TL, Cullen JJ, Kelly DE, Lewis MR (1998) Potential contribution of vertically migrating Rhizosolenia to nutrient cycling and new production in the subtropical North Pacific Ocean. J Plankton Res 20:219-241

Roenneberg T, Carpenter EJ (1993) Daily rhythm of $\mathrm{O}_{2}$ evolution in the cyanobacterium Trichodesmium thiebautii under natural and constant conditions. Mar Biol 117: 693-697

Sverdrup HU, Johnson MW, Fleming RH (1946) The Oceans, their physics, chemistry and general biology, PrenticeHall, New York

Editorial responsibility: Otto Kinne (Editor-in-Chief), Oldendorf/Luhe, Germany
Villareal TA (1995) Abundance and photosynthetic characteristics of Trichodesmium spp. along the Atlantic Barrier Reef at Carrie Bow Cay, Belize. PSZN I: Mar Ecol 16: $259-271$

Villareal TA, Carpenter EJ (1990) Diel buoyancy in the marine diazotrophic cyanobacterium Trichodesmium thiebautii. Limnol Oceanogr 35:1832-1837

Villareal TA, Carpenter EJ (2003) Buoyancy regulation and potential for vertical migration in the oceanic cyanobacterium Trichodesmium. Microb Ecol 45:1-10

Villareal TA, Altabet MA, Culver-Rymsza K (1993) Nitrogen transport by vertically migrating diatom mats in the North Pacific Ocean. Nature 363:709-712

Visser P, Passarge J, Mur LR (1997) Modeling vertical migration of the cyanobacterium Microcystis. Hydrobiologia 349:99-109

Wallace B, Hamilton D (1999) The effects of variation in irradiance on buoyancy in Microcystis aeruginos. Limnol Oceanogr 44:273-281

Walsby AE (1978) Mechanisms of buoyancy regulation by planktonic cyanobacteria with gas vesicles. In: Fay P, Van Baalen C (eds) The Cyanobacteria. Elsevier, Amsterdam

Walsby AE (1992) The gas vesicles and buoyancy of Trichodesmium. In: Carpenter EJ, Capone DG, Rueter JG (eds) Marine pelagic Cyanobacteria: Trichodesmium and other diazotrophs. Kluwer Academic Publishers, Norwell, MA, p 141-163

Walsby AE, Reynolds CS (1980) Sinking and floating. In: Morris I (ed) The physiological ecology of phytoplankton. University of California Press, Berkeley, CA, p $371-412$

White AE, Spitz YH, Karl DM, Letelier RM (2006) Flexible elemental stoichiometry in Trichodesmium spp. and its ecological implications. Limnol Oceanogr 51:1777-1790

Submitted: December 9, 2005; Accepted: April 7, 2006 Proofs received from author(s): September 22, 2006 